\title{
BMJ
}

\section{Neuraminidase inhibitors for treatment and prophylaxis of influenza in children:systematic review and meta-analysis of randomised controlled trials}

\author{
Matthew Shun-Shin, academic foundation year 2 doctor, ${ }^{1}$ Matthew Thompson, senior clinical scientist, ${ }^{2}$ \\ Carl Heneghan, clinical lecturer, ${ }^{2}$ Rafael Perera, university lecturer in medical statistics, ${ }^{2}$ Anthony Harnden, \\ university lecturer in general practice, ${ }^{2}$ David Mant, professor of general practice ${ }^{2}$
}

\begin{abstract}
${ }^{1}$ Kadoorie Centre, John Radcliffe Hospital, Headington, Oxford OX3 9DU

${ }^{2}$ Oxford University Department of Primary Health Care, Rosemary

Rue Building, Headington, Oxford OX3 7LF

Correspondence to: $\mathrm{M}$ Thompson matthew.thompson@dphpc.ox.ac uk

Cite this as: BMJ 2009;339:b3172 doi:10.1136/bmj.b3172
\end{abstract}

\section{ABSTRACT}

Objective To assess the effects of the neuraminidase inhibitors oseltamivir and zanamivir in treatment of children with seasonal influenza and prevention of transmission to children in households.

Design Systematic review and meta-analysis of data from published and unpublished randomised controlled trials.

Data sources Medline and Embase to June 2009, trial registries, and manufacturers and authors of relevant studies.

exacerbations or the use of antibiotics. Their effects on A/H1N1 influenza strain remain to be determined.

\section{INTRODUCTION}

Review methods Eligible studies were randomised controlled trials of neuraminidase inhibitors in children aged $\leq 12$ in the community (that is, not admitted to hospital) with confirmed or clinically suspected influenza. Primary outcome measures were time to resolution of illness and incidence of influenza in children living in households with index cases of influenza.

Results We identified four randomised trials of treatment of influenza (two with oseltamivir, two with zanamivir) involving 1766 children (1243 with confirmed influenza, of whom $55-69 \%$ had influenza $A$ ), and three randomised trials for postexposure prophylaxis (one with oseltamivir, two with zanamivir) involving 863 children; none of these trials tested efficacy with the current pandemic strain. Treatment trials showed reductions in median time to resolution of symptoms or return to normal activities, or both, of 0.5-1.5 days, which were significant in only two trials. A 10 day course of postexposure prophylaxis with zanamivir or oseltamivir resulted in an $8 \%(95 \%$ confidence interval $5 \%$ to $12 \%$ ) decrease in the incidence of symptomatic influenza. Based on only one trial, oseltamivir did not reduce asthma exacerbations or improve peak flow in children with asthma. Treatment was not associated with reduction in overall use of antibiotics (risk difference $-0.30,-0.13$ to 0.01 ). Zanamivir was well tolerated, but oseltamivir was associated with an increased risk of vomiting $(0.05,0.02$ to 0.09 , number needed to harm=20).

Conclusions Neuraminidase inhibitors provide a small benefit by shortening the duration of illness in children with seasonal influenza and reducing household transmission. They have little effect on asthma the incidence of serious complications, and on the current

During epidemic years, influenza attack rates often exceed 40\% in preschool children and 30\% in school age children. ${ }^{1}$ School age children are the main source of spread of influenza into households. In some influenza seasons, a quarter of children presenting to emergency departments and paediatric clinics with respiratory symptoms or fever will have laboratory evidence of influenza. ${ }^{2}$ Moreover, complications of influenza are common in children and include respiratory tract infections (acute otitis media, sinusitis, bronchitis, bronchiolitis, croup), febrile convulsions, and exacerbations of asthma. Acute otitis media, for example, occurs in 20-50\% of children under 6 after influenza. ${ }^{3}$ In contrast, deaths from seasonal influenza are rare. During the 2003-4 influenza season in the United States, 2.1 per million children died from influenza or its complications, such as pneumonia. ${ }^{4}$ In the current $\mathrm{H} 1 \mathrm{~N} 1$ pandemic, about $30 \%$ of cases in the United Kingdom have been in children aged under $10 .^{5}$

The primary strategy for control of influenza is vaccination. ${ }^{6}$ Coverage, however, might be low, and often there is inadequate time to produce and distribute vaccines in response to emerging strains, such as influenza $\mathrm{A} / \mathrm{H} 5 \mathrm{~N} 1$ and the new variant influenza $\mathrm{A} /$ H1N1 (Mexico). Therefore, current control strategies include using antiviral medications for preventing spread, as well as for treating infected individuals. Because amantadine and rimantidine are effective only against influenza A, are limited by drug resistance, and have poor tolerability, they have been replaced by neuraminidase inhibitors. ${ }^{7}$ Oseltamivir (Tamiflu) is administered orally and in the UK is licensed for the treatment and postexposure prophylaxis of influenza in children aged over 1. Zanamivir (Relenza) is inhaled as a dry powder and is currently licensed in the UK for the treatment and postexposure 
Potentially relevant records identified and screened $(n=4917)$

Not relevant based on titles and abstract $(n=4882)$

Records retrieved for more detailed assessment $(n=35)$

Excluded $(n=28)$ :

Not an RCT $(n=19)$

Comparison not focus of review $(n=2)$

Not in children $(n=5)$

Not in community $(\mathrm{n}=1)$

Unable to obtain data $(n=1)$

Trials eligible for inclusion $(n=7)$

Fig 1 | Flowchart of search results

prophylaxis of influenza in children aged 5 and over. For treatment to be effective, current guidelines for treating seasonal influenza state that oseltamivir should be administered within 48 hours and zanamivir within 36 hours of onset of symptoms. ${ }^{8}$

The last update of our Cochrane review of this treatment was in 2005 and included three treatment trials and one prophylaxis trial. ${ }^{9}$ We need an accurate, up to date assessment of the benefits and harms of oseltamivir and zanamivir so that national bodies, clinicians, and parents can make evidence informed decisions about treating and preventing influenza in children. We assessed the current evidence for the effectiveness, safety, and tolerability of neuraminidase inhibitors for the treatment and prevention of influenza in children.

\section{METHODS}

\section{Eligibility and search strategy}

We included all published and unpublished randomised controlled trials that compared the use of neuraminidase inhibitors in the treatment and prophylaxis of influenza in children aged 12 and under that we considered sufficiently free from bias. There were no language restrictions. We searched Medline (1966 to 1 July 2009), Embase (1980 to 28 June 2009), the clinical trial registries of the manufacturers of oseltamivir and zanamivir (GlaxoSmithKline and Roche Pharmaceuticals, respectively), the Cochrane central register of controlled trials ( Cochrane Library 2009, Issue 2), and www.controlled-trials.com (a meta-registry of randomised controlled clinical trials that includes the ISRCTN register). Search terms were "relenza" OR "zanamivir" OR "tamiflu" OR "oseltamivir" OR "neuraminidase inhibitor". We also hand searched reference lists of retrieved papers, relevant NICE guidelines, and technology reports from the UK Health Technology Assessment programme. ${ }^{81011}$ The two pharmaceutical manufacturers provided us with unpublished data, and we contacted authors for clarification as needed.

\section{Assessment of risk of bias}

Using the Cochrane "risk of bias" tool, ${ }^{12}$ we assessed all studies for the quality or appropriateness of allocation, blinding, and management of incomplete outcome data and the completeness of reporting of outcomes. We also evaluated baseline differences and methodological issues.

\section{Data abstraction}

Two authors (MS-S, MT) independently extracted data from included trials, including year, participants (age range, inclusion criteria, influenza test results), intervention, and results (outcome measures, effect, significance, adverse events). Disagreements in extracted data were resolved by discussion with a third review author $(\mathrm{CH})$. Two authors (MS-S, MT) assessed trial quality. As the incidence of microbiologically confirmed influenza in participants recruited with influenza-like symptoms is variable, we analysed efficacy separately for all participants with influenza-like symptoms ("clinical influenza") and for those with microbiologically confirmed influenza ("confirmed influenza"). We sought data on primary outcome measures of time to resolution of the illness in treatment trials and the attack rate of symptomatic influenza in children during the period of prophylaxis in prevention trials. Secondary outcome measures included time to resolution of individual symptoms; time to return to school, day care, or normal activity; effect on respiratory function in children with asthma; and adverse events.

\section{Data analysis}

We extracted the median number of days, with 95\% confidence intervals as available, to resolution or improvement of clinical features of influenza, including global change. When appropriate we pooled global change scores. We calculated risk differences and 95\% confidence intervals for dichotomous outcomes and used the $\mathrm{I}^{2}$ statistic to measure the level of statistical heterogeneity for each outcome. ${ }^{13}$ When no heterogeneity was detected, we performed a random effects meta-analysis. When there was substantial heterogeneity $\left(\mathrm{I}^{2}>50 \%\right)$, we considered possible explanations for this and considered not combining results. We used sensitivity analysis when necessary to investigate the contribution of individual trials to any heterogeneity. Subgroup analyses included type of neuraminidase inhibitor and children with clinical or confirmed influenza. We used Review Manager version 5.0 for statistical analysis.

\section{RESULTS}

We identified 4917 articles (fig 1), and two authors independently reviewed 35 full text articles to identify those that met inclusion criteria. One further unpublished trial was found from the GlaxoSmithKline registry. ${ }^{\mathrm{w} 1}$ Seven randomised controlled trials met our inclusion criteria; four of these were studies of treatment of influenza ${ }^{\mathrm{w1}-\mathrm{w} 4}$ and three of postexposure prophylaxis of influenza contacts in households. ${ }^{\text {w-w7 }}$ Six of the seven trials used clinical criteria for enrolment, ${ }^{\text {w2-w7 }}$ with virological tests performed at a later date to produce a post hoc group of confirmed cases; one used near patient testing for influenza at enrolment. ${ }^{\text {w1 }}$ One trial confirmed the presence of influenza with near 
patient testing only in those participants who had received influenza vaccination in the current season. ${ }^{\mathrm{w} 2}$

Two of the treatment trials tested inhaled zanami$v \mathrm{rir}^{\mathrm{w} 1 \mathrm{w} 2}$ and two tested oral oseltamivir ${ }^{\mathrm{w} 3 \mathrm{w} 4}$ in a total of 1766 children, of whom 1243 had confirmed influenza (table 1). Three trials recruited otherwise healthy children, ${ }^{\text {w1-w3 }}$ while one specifically recruited children with asthma. ${ }^{\mathrm{w} 4}$ In the three treatment trials that reported influenza type, 55-69\% of participants had influenza A. ${ }^{\text {w2-w4 }}$ The treatment trials reported the primary outcome measure of time to resolution of influenza in two ways: median time to resolution of illness, which was a composite outcome comprising resolution or alleviation of symptoms and resolution of fever and return to school or normal activity ${ }^{\mathrm{w} 3} \mathrm{w} 4$; and/or median time to resolution or alleviation of symptoms of influenza (including cough, fever, muscle and joint aches, sore throat, headache, and fever). ${ }^{\mathrm{wl}-\mathrm{w} 4}$ Two trials ${ }^{\mathrm{w} 3 \mathrm{w}}{ }^{\mathrm{w}}$ used the Canadian acute respiratory infection and flu scale (CARIFS). ${ }^{14}$

For postexposure prophylaxis, we identified two trials of zanamivir ${ }^{\mathrm{w} 5}{ }^{\mathrm{w} 6}$ and one trial of oseltamivir, ${ }^{\mathrm{w} 7}$ which involved a total of 863 paediatric contacts (427 intervention, 436 control) (table 2). All three trials randomised households as units to receive the same treatment. The drug given to the index case varied in all trials. In the oseltamivir trial all index cases received the active drug $^{\mathrm{w} 7}$; in one of the zanamivir trials the index cases were given the same treatment as the household (zanamivir or placebo) ${ }^{\mathrm{w} 5}$; and in the other zanamivir trial the index case did not receive any study drug. ${ }^{\text {w6 }}$ The primary outcome measured in these trials was the attack rate of symptomatic influenza in children during the period of prophylaxis.

\section{Assessment of quality of trials}

Only one treatment trial reported sufficient detail of the methods to be judged as high quality. ${ }^{\text {w2 }}$ The three others did not report sufficient details to determine whether allocation concealment and blinding were adequate (table 3). ${ }^{\mathrm{w} 1 \mathrm{w} 3 \mathrm{w} 4}$ The three trials of postexposure prophylaxis were of moderate quality. ${ }^{\text {w5-w7 }}$ Two had insufficient details about allocation concealment ${ }^{\mathrm{w} 5}$ ${ }^{\mathrm{w} 6}$ and one was open labelled (not blinded). ${ }^{\mathrm{w} 7}$ The baseline comparison data for paediatric contacts (all trials) was not available, but no differences were apparent in the data for all ages.

Effect of treatment on time to resolution of symptoms, resolution of illness, and return to school or normal activity Treatment with zanamivir and oseltamivir provided a median reduction in time to resolution of symptoms of between 0.5 and 1.5 days (table 4). In children with confirmed influenza, one trial with zanamivirw2 and one with oseltamivir ${ }^{\mathrm{w} 3}$ showed significant reductions in the median time to resolution of influenza symptoms

Table 1 Characteristics of the trials of zanamivir and oseltamivir for treatment of influenza*

\begin{tabular}{|c|c|c|c|c|c|c|c|c|c|}
\hline \multirow[b]{2}{*}{ Trial (drug) } & \multirow[b]{2}{*}{ Inclusion criteria } & \multirow[b]{2}{*}{ Exclusion criteria } & \multirow[b]{2}{*}{$\begin{array}{l}\text { Age range (years) } \\
\text { (median } \\
\text { intervention, } \\
\text { contol) }\end{array}$} & \multicolumn{2}{|c|}{ Intervention } & \multicolumn{2}{|c|}{ Control } & \multirow[b]{2}{*}{$\begin{array}{c}\text { Outcomes } \\
\text { reported }\end{array}$} & \multirow[b]{2}{*}{$\begin{array}{l}\text { Duration of } \\
\text { follow-up } \\
\text { (days) }\end{array}$} \\
\hline & & & & $\begin{array}{l}\text { Recruited } \\
\text { (vaccina- } \\
\text { ted) }\end{array}$ & $\begin{array}{l}\text { Confirmed } \\
\text { (vaccina- } \\
\text { ted) }\end{array}$ & $\begin{array}{l}\text { Recruited } \\
\text { (vaccina- } \\
\text { ted) }\end{array}$ & $\begin{array}{l}\text { Confirmed } \\
\text { (vaccina- } \\
\text { ted) }\end{array}$ & & \\
\hline $\begin{array}{l}\text { NAl30009 }{ }^{\mathrm{w} 2}, 1998- \\
\text { 9, US, Canada, } \\
\text { Europe, Israel } \\
\text { (zanamivir) }\end{array}$ & $\begin{array}{l}\text { Influenza-like } \\
\text { illness of } \leq 36 \mathrm{hr} \\
\text { duration + temp } \\
\geq 37.8^{\circ} \mathrm{C}+\text { no } \\
\text { evidence of } \\
\text { bacterial infection }\end{array}$ & $\begin{array}{l}\text { Immunosuppres- } \\
\text { sed, cystic fibrosis, } \\
\text { underlying } \\
\text { condition that } \\
\text { would prevent data } \\
\text { collection }\end{array}$ & $5-12($ mean $8.5,8.9)$ & $224(6)$ & $164(2)$ & $247(5)$ & $182(1)$ & $\begin{array}{l}\text { Timeto alleviation of } \\
\text { symptoms, } \\
\text { apyrexia, return to } \\
\text { normal activity. } \\
\text { Incidence of } \\
\text { complications. Use } \\
\text { of antibiotics }\end{array}$ & 28 \\
\hline $\begin{array}{l}\text { NAI30028 } 8^{\mathrm{w} 1} \dagger, 2000- \\
1, \text { Germany } \\
\text { (zanamivir) }\end{array}$ & $\begin{array}{l}\text { Influenza-like } \\
\text { illness of }<48 \mathrm{hr} \\
\text { duration + temp } \\
\geq 37.8^{\circ} \mathrm{C}+\text { no } \\
\text { evidence of } \\
\text { bacterial infection. } \\
\text { Rapid influenza test } \\
\text { positive }\end{array}$ & Not reported & $5-12(7,8)$ & $176(N A)$ & $176(N A)$ & 90 (NA) & 90 (NA) & $\begin{array}{l}\text { Timeto alleviation of } \\
\text { symptoms, return to } \\
\text { school. Incidence of } \\
\text { complications }\end{array}$ & 5 \\
\hline $\begin{array}{l}\text { WV15758 }{ }^{\text {w3 }}, 1998-9, \\
\text { US, Canada } \\
\text { (oseltamivir) }\end{array}$ & $\begin{array}{l}\text { Influenza-like } \\
\text { illness of }<48 \mathrm{hr} \\
\text { duration (temp } \\
\geq 37.8^{\circ} \mathrm{C} \text { and at least } \\
\text { one of cough or } \\
\text { coryza) }\end{array}$ & $\begin{array}{l}\text { RSV rapid test } \\
\text { positive, HIV } \\
\text { positive, } \\
\text { immunosuppres- } \\
\text { sed, poorly } \\
\text { controlled systemic } \\
\text { illness }\end{array}$ & $1-12(5,5)$ & 344 (11) & $217(4)$ & $351(10)$ & $235(6)$ & $\begin{array}{l}\text { Time to resolution of } \\
\text { symptoms, return to } \\
\text { daycare/school, } \\
\text { apyrexia. Change in } \\
\text { CARIF score }\end{array}$ & 28 \\
\hline $\begin{array}{l}\text { WV15759/ } \\
\text { WV15871 }{ }^{\text {w4 }}, 1998-9, \\
\text { northern and } \\
\text { southern } \\
\text { hemispheres } \\
\text { (oseltamivir) }\end{array}$ & $\begin{array}{l}\text { Asthma and }<48 \mathrm{hr} \\
\text { influenza symptoms } \\
\text { (temp } \geq 37.8^{\circ} \mathrm{C} \text { and } \\
\text { cough or coryza) }\end{array}$ & $\begin{array}{l}\text { RSV rapid test } \\
\text { positive, HIV } \\
\text { positive, } \\
\text { immunosuppres- } \\
\text { sed, uncontrolled } \\
\text { renal, vascular, } \\
\text { neurological, } \\
\text { metabolic disease }\end{array}$ & $5-12(9,9)$ & $170(31)$ & 84 (14) & $164(34)$ & $95(11)$ & $\begin{array}{l}\text { Time alleviation of } \\
\text { symptoms, return to } \\
\text { normal activity, } \\
\text { apyrexia. Change in } \\
\text { peak expiratory flow } \\
\text { from baseline. } \\
\text { Change in CARIF } \\
\text { score }\end{array}$ & 28 \\
\hline
\end{tabular}


Table 2 |Characteristics of trials of zanamivir and oseltamivir for postexposure prophylaxis of influenza*

\begin{tabular}{|c|c|c|c|c|c|c|c|}
\hline \multirow[b]{2}{*}{ Trial } & \multirow[b]{2}{*}{ Treatment } & \multicolumn{2}{|c|}{ Intervention } & \multicolumn{2}{|c|}{ Control } & \multirow[b]{2}{*}{ Outcomes } & \multirow[b]{2}{*}{$\begin{array}{c}\text { Duration of follow } \\
\text { up (days) }\end{array}$} \\
\hline & & $\begin{array}{l}\text { Index cases } \\
\text { (confirmed) }\end{array}$ & $\begin{array}{l}\text { Paediatric } \\
\text { contacts }\end{array}$ & $\begin{array}{l}\text { Index cases } \\
\text { (confirmed) }\end{array}$ & $\begin{array}{l}\text { Paediatric } \\
\text { contacts }\end{array}$ & & \\
\hline $\begin{array}{l}\text { NAI30010 }{ }^{\mathrm{w} 5} \dagger, 1998- \\
9, \text { US, Canada, } \\
\text { Finland, UK }\end{array}$ & $\begin{array}{l}\text { Index: zanamivir } 10 \text { mg inhaled twice daily for } \\
5 \text { days or placebo. Contacts: zanamivir } 10 \mathrm{mg} \\
\text { inhaled twice daily for } 10 \text { days or placebo. } \\
\text { Excluded: immunosuppressed }\end{array}$ & $163(78)$ & 135 & $158(79)$ & 142 & $\begin{array}{l}\text { Symptomatic, } \\
\text { laboratory confirmed } \\
\text { influenza during the } \\
10 \text { days on prophylaxis }\end{array}$ & $\begin{array}{l}\text { Index: up to } \\
14 \text { days. Contacts: } \\
28 \text { days }\end{array}$ \\
\hline $\begin{array}{l}\text { NAl30031 }{ }^{\text {w6 }} \dagger, 2000- \\
1,59 \text { sites in } \\
\text { Australasia, Europe, } \\
\text { South Africa, US }\end{array}$ & $\begin{array}{l}\text { Index: not treated. Contacts: zanamivir } 10 \mathrm{mg} \\
\text { inhaled twice daily for } 10 \text { days or placebo. } \\
\text { Excluded: severe persistent asthma, already } \\
\text { had symptomatic influenza }\end{array}$ & 245 (129) & 188 & 242 (153) & 183 & $\begin{array}{l}\text { Symptomatic, } \\
\text { laboratory confirmed } \\
\text { influenza during the } \\
10 \text { days on prophylaxis }\end{array}$ & $\begin{array}{l}\text { Index: } 28 \text { days. } \\
\text { Contacts: } 28 \text { days }\end{array}$ \\
\hline $\begin{array}{l}\text { WV16193 }{ }^{\mathrm{w} 7}, 2000-1 \\
\text { Europe and North } \\
\text { America }\end{array}$ & $\begin{array}{l}\text { Index: oseltamivir } 30,45 \text {, or } 60 \text { mg based on } \\
\text { age (1-3, 4-5, 6-12) twice daily for } 5 \text { days. } \\
\text { Contacts: oseltamivir } 30,45 \text {, or } 60 \text { mg based } \\
\text { on age (1-3, 4-5, 6-12) once daily for } 10 \text { days. } \\
\text { Excluded: immunosuppressed, HIV infection, } \\
\text { liver, renal, or significant cardiac disease }\end{array}$ & $138(84)$ & 104 & 139 (98) & 111 & $\begin{array}{l}\text { Symptomatic, } \\
\text { laboratory confirmed } \\
\text { influenza during the } \\
10 \text { days on prophylaxis }\end{array}$ & $\begin{array}{l}\text { Index: } 30 \text { days. } \\
\text { Contacts: } 30 \text { days }\end{array}$ \\
\hline
\end{tabular}

*Inclusion criteria for all studies: one member with influenza-like illness in household when influenza transmission was confirmed in local area.

†Unpublished subgroup data supplied by manufacturer.

from 5.25 to 4.0 days (difference 1.25 days, $95 \%$ confidence interval 0.5 to 2.0 days, $\mathrm{P}<0.001$ ) and from 4.2 to 2.6 days (difference 1.5 days, 0.25 to 2.5 days, $\mathrm{P}<0.001$ ), respectively. A further trial of oseltamivir reported a similar but non-significant reduction in median time to resolution of influenza symptoms from 4.8 to 3.8 days (difference 1.1 days, confidence interval not reported, $\mathrm{P}=0.12) .{ }^{\mathrm{w} 4}$ One trial of zanamivir reported a smaller reduction in median time to resolution of symptoms from 5.5 to 5.0 days but did not report either a confidence interval or $\mathrm{P}$ value. ${ }^{\mathrm{w}}$ Only one trial reported the median time to resolution of symptoms in children with clinical influenza and found a significant reduction from 5.0 to 4.5 days (difference 0.5 days, 0.0 to 1.5 days, $\mathrm{P}=0.01) \mathrm{.}^{\mathrm{w} 2}$

The two oseltamivir trials reported a reduction of between 0.4 and 1.5 days in the median time to resolution of illness, defined as resolution of all symptoms and resolution of fever and return to school or normal activities (table 4). In children with confirmed influenza, oseltamivir provided a significant reduction in median time to resolution of illness from 5.7 to 4 . 2 days (difference 1.5 days, 0.3 to 2.5 days, $\mathrm{P}<0.001$ ) in one $\mathrm{w}^{\mathrm{w} 3}$ trial and a non-significant reduction from 5.6 to 5.2 days (difference 0.4 days, confidence interval not reported, $\mathrm{P}=0.54$ ) in the second trial. ${ }^{\mathrm{w} 4}$ In children with clinical influenza, one oseltamivir trial reported a reduction in time to resolution of illness from 5.3 to 4 . 4 days (difference 0.9 days, 0.2 to 1.9 days, $\mathrm{P}<0.001$ ). ${ }^{\text {w3 }}$

\begin{tabular}{|c|c|c|c|c|c|c|c|c|c|c|}
\hline \multirow{2}{*}{$\begin{array}{l}\text { Study or } \\
\text { subgroup }\end{array}$} & \multicolumn{2}{|c|}{ Antiviral } & \multicolumn{2}{|c|}{ Placebo } & \multirow{2}{*}{\multicolumn{4}{|c|}{$\begin{array}{c}\text { Random risk } \\
\text { difference } \\
\text { (random) }(95 \% \mathrm{Cl})\end{array}$}} & \multirow{2}{*}{$\begin{array}{l}\text { Weight } \\
\text { (\%) }\end{array}$} & \multirow{2}{*}{$\begin{array}{c}\text { Random risk } \\
\text { difference } \\
(\text { random })(95 \% \mathrm{Cl})\end{array}$} \\
\hline & Events & Total & Events & $\overline{\text { Total }}$ & & & & & & \\
\hline NA130009 & 19 & 164 & 27 & 182 & & & & & 57.0 & $-0.03(-0.10$ to 0.04$)$ \\
\hline WV15758 & 68 & 217 & 97 & 235 & & & & & 43.0 & $-0.10(-0.19$ to -0.01$)$ \\
\hline Total & 87 & 381 & 124 & 417 & & & & & 100.0 & $-0.06(-0.13$ to 0.01$)$ \\
\hline \multicolumn{5}{|c|}{$\begin{array}{l}\text { Test for heterogeneity: } \tau^{2}=0.00, \chi^{2}=1.51 \text {, } \\
d f=1, P=0.22,\left.\right|^{2}=34 \%\end{array}$} & -0.2 & -0.1 & & 0.1 & 0.2 & \\
\hline \multicolumn{5}{|c|}{ Test for overall effect: $z=1.74, P=0.08$} & $\begin{array}{l}\text { Favc } \\
\text { anti }\end{array}$ & & & \multicolumn{2}{|c|}{$\begin{array}{l}\text { Favours } \\
\text { placebo }\end{array}$} & \\
\hline
\end{tabular}

Fig 2 | Incidence of antibiotic use in children with confirmed influenza
Three treatment trials reported the effects of treatment on return to school or normal activity (table 4). ${ }^{\mathrm{w}}$ w2 w4 One trial found that children given zanamivir returned to school or normal activity one day sooner in those with confirmed influenza $(\mathrm{P}=0.019)$, as well as in those with clinical influenza $(\mathrm{P}=0.022){ }^{\mathrm{w} 2}$ The other zanamivir trial reported that, by day five, $36 \%(62 / 172)$ of children given zanamivir and 28\% (25/89) of controls had returned to school or normal activity (risk difference $0.08,-0.04$ to $0.20, \mathrm{P}=0.19){ }^{\mathrm{w} 1}$ The one oseltamivir trial that reported this outcome found a nonsignificant reduction in median time to return to school from 4.8 to 4.2 days (difference 0.6 , confidence interval not reported, $\mathrm{P}=0.46$ ) in children with confirmed influenza. $^{\text {w4 }}$

Two trials provided data on the natural course of confirmed influenza in children. ${ }^{\text {w2 }}{ }^{\text {w3 }}$ Resolution of illness occurred in $75 \%$ of children within 8.7 days $(90 \%$ within 14.2 days). ${ }^{\text {w2 }}$ Alleviation of all symptoms occurred in $75 \%$ of children within 7.3 days $(90 \%$ within 13 days). ${ }^{\mathrm{w}}$

Effect of treatment on reduction in cough or fever Two of the three ${ }^{\mathrm{w} 1-\mathrm{w} 3}$ trials that reported effects of treatment on cough showed significant effects: oseltamivir reduced the median duration of cough by 1.3 days in children with confirmed influenza in one trial $(\mathrm{P}<0.001),{ }^{\mathrm{w} 3}$ and zanamivir reduced the incidence of "moderate or severe cough" at day five in children with confirmed influenza in a second trial $(\mathrm{P}=0.001),{ }^{\text {w2 }}$ but no magnitude of effect was reported. Of the two trials that reported the median duration of fever, ${ }^{\mathrm{w} 1 \mathrm{w} 3}$ there was a significant reduction of one day in the one trial of oseltamivir $(\mathrm{P}<0.001)^{\mathrm{w} 3}$ and a reduction of 0.5 days (significance not reported) in one trial of zanamivir. ${ }^{\text {w }}$

Effect of treatment on change in asthma severity

One trial of oseltamivir specifically recruited children with asthma. ${ }^{\mathrm{w} 4}$ Treatment did not reduce the number of asthma exacerbations in children with confirmed 


\begin{tabular}{|c|c|c|c|c|c|c|c|c|c|c|}
\hline \multirow{2}{*}{$\begin{array}{l}\text { Study or } \\
\text { subgroup }\end{array}$} & \multicolumn{2}{|c|}{ Antiviral } & \multicolumn{2}{|c|}{ Placebo } & \multirow{2}{*}{\multicolumn{4}{|c|}{$\begin{array}{c}\text { Random risk } \\
\text { difference } \\
\text { (random) }(95 \% \mathrm{Cl})\end{array}$}} & \multirow{2}{*}{$\begin{array}{l}\text { Weight } \\
\text { (\%) }\end{array}$} & \multirow{2}{*}{$\begin{array}{c}\text { Random risk } \\
\text { difference } \\
(\text { random })(95 \% \mathrm{Cl})\end{array}$} \\
\hline & Events & Total & Events & Total & & & & & & \\
\hline NA130010 & 3 & 135 & 13 & 142 & & & $\longrightarrow-$ & & 42.6 & $-0.07(-0.12$ to -0.02$)$ \\
\hline NA130031 & 7 & 188 & 22 & 183 & & & $\longrightarrow$ & & 41.4 & $-0.08(-0.14$ to -0.03$)$ \\
\hline WV16193 & 7 & 104 & 21 & 111 & & & $\rightarrow$ & & 16.0 & $-0.12(-0.21$ to -0.03$)$ \\
\hline Total & 17 & 427 & 56 & 436 & & & & & 100.0 & $-0.08(-0.12$ to -0.05 \\
\hline \multicolumn{5}{|c|}{$\begin{array}{l}\text { Test for heterogeneity: } \tau^{2}=0.00, \chi^{2}=1.09 \text {, } \\
d f=2, P=0.58, I^{2}=0 \%\end{array}$} & -0.3 & -0.2 & -0.1 & 0 & $0.1 \quad 0.2$ & \\
\hline \multicolumn{5}{|c|}{ Test for overall effect: $z=4.68, P<0.001$} & & & & & & \\
\hline
\end{tabular}

Fig 3 Incidence of confirmed symptomatic influenza in paediatric contacts of index cases with clinical influenza

influenza (risk difference $-0.05,-0.15$ to $0.05, \mathrm{P}=0.34$ ) or improve median change in peak flow between study entry and day six $(\mathrm{P}=0.35)$ compared with controls. The trial did, however, identify a small improvement in the forced expiratory volume in one second $\left(\mathrm{FEV}_{1}\right)$ between study entry and day six (median improvement $10.8 \% v 4.7 \%, \mathrm{P}=0.01)$. One trial of 471 children with clinical influenza (of whom $36(8 \%)$ had unspecified concurrent chronic respiratory conditions requiring regular medication) showed no significant difference in asthma exacerbations between zanamivir and control $(-0.01,-0.03$ to $0.01, \mathrm{P}=0.30) .{ }^{\text {w2 }}$ Combining the results with a random effects model showed no significant change in asthma exacerbations with neuraminidase inhibitor treatment $(-0.02,-0.05$ to 0.02 , $\left.\mathrm{P}=0.27, \mathrm{I}^{2}=16 \%\right)$.

\section{Effect of treatment on antibiotic use}

Two trials reported the effect of treatment on overall use of antibiotics. In one, treatment with oseltamivir was associated with a $10 \%$ reduction in overall antibiotic use in children with confirmed influenza (risk difference $-0.10,-0.19$ to $-0.01, \mathrm{P}=0.03) .{ }^{\mathrm{w} 3}$ In contrast, treatment with zanamivir did not reduce overall antibiotic use in children with confirmed influenza $(-0.03,-0.10$ to $0.04, \mathrm{P}=0.37) .{ }^{\mathrm{w} 2}$ Combining these results with a random effects model showed a non-significant reduction in antibiotic use (fig 2) $(-0.06,-0.13$ to $\left.0.01, \mathrm{P}=0.08, \mathrm{I}^{2}=34 \%\right)$.

Effect of treatment on otitis media

Treatment had no effect on the incidence of otitis media (risk difference $-0.01,-0.04$ to $0.02 ; \mathrm{P}=0.92$, $\mathrm{I}^{2}=0 \%$ ) in two trials of children aged 5-12 (who had an overall incidence of otitis media of $6 \%){ }^{\mathrm{w} 1 \mathrm{w} 4}$ In a third trial, ${ }^{\text {w3 }}$ as reported in a separate abstract, ${ }^{\mathrm{w} 8}$ in children with confirmed influenza treatment with oseltamivir had no effect on the development of otitis media (confirmed with tympanometry) at day 10 in children aged $6-12(-0.02,-0.11$ to $0.06, \mathrm{P}=0.57)$ but did reduce the incidence of otitis media from $31 \%$ to $15 \%$ in children aged $1-5(-0.16,-0.29$ to $-0.04, \mathrm{P}=0.009)$.

\section{Effect of postexposure prophylaxis}

A 10 day course of prophylaxis with either zanamivir $^{\mathrm{w} 5 \mathrm{w} 6}$ or oseltamivir ${ }^{\mathrm{w} 7}$ was associated with an $8 \%$ reduction (risk difference $-0.08,-0.12$ to -0.05 , $\left.\mathrm{P}<0.001, \mathrm{I}^{2}=0 \%\right)$ in the risk of developing confirmed symptomatic influenza after the introduction of an index case of clinical influenza into the household. This equates to a number needed to treat of 13 (9 to 20) to prevent one additional household case of symptomatic influenza (fig 3).

\section{Safety and tolerability of oseltamivir and zanamivir}

The four treatment trials reported on tolerability and adverse events. ${ }^{\mathrm{wl}-\mathrm{w} 4}$ Overall reported adherence was high; $97 \%$ of participants took more than eight of the 10 doses of zanamivir, ${ }^{\text {w2 }}$ and $90 \%$ took all 10 doses of oseltamivir. ${ }^{\text {w3 }}$ There was no significant difference in the number of withdrawals because of adverse events between either zanamivir or oseltamivir and placebo.

Table $3 \mid$ Assessment of methodological quality

\begin{tabular}{|c|c|c|c|c|c|c|c|}
\hline & \multicolumn{4}{|c|}{ Treatment trials } & \multicolumn{3}{|c|}{ Postexposure prophylaxis trials } \\
\hline & NAI30009w2 & NAI30028w1* & WV15758w3 & WV15759/WV15871w4 & NAI30010w5 & NAI30031w6 & WV16193w7 \\
\hline $\begin{array}{l}\text { Adequate } \\
\text { sequence } \\
\text { generation }\end{array}$ & $\begin{array}{l}\text { Blindly assigned to } \\
\text { zanamivir or placebo in } \\
1: 1 \text { ratio by computer- } \\
\text { generated randomisation } \\
\text { schedule }\end{array}$ & $\begin{array}{l}\text { Randomised, but } \\
\text { no further details } \\
\text { given }\end{array}$ & $\begin{array}{l}\text { Block } \\
\text { randomisation by } \\
\text { site. Stratified by } \\
\text { presence of otitis } \\
\text { media }\end{array}$ & $\begin{array}{l}\text { Randomised, no further } \\
\text { details }\end{array}$ & $\begin{array}{l}\text { Randomised by } \\
\text { household, no } \\
\text { further details }\end{array}$ & $\begin{array}{l}\text { Randomised by } \\
\text { household, no } \\
\text { further details }\end{array}$ & $\begin{array}{l}\text { Randomised by } \\
\text { household, no further } \\
\text { details }\end{array}$ \\
\hline $\begin{array}{l}\text { Allocation } \\
\text { concealment }\end{array}$ & Yes & Insufficient detail & Insufficient detail & Insufficient detail & Insufficient detail & Insufficient detail & Open label \\
\hline Blinding & $\begin{array}{l}\text { Randomisation code } \\
\text { broken after study was } \\
\text { complete and all data had } \\
\text { been entered and verified } \\
\text { in database }\end{array}$ & $\begin{array}{l}\text { Double blind, } \\
\text { "zanamivir } \\
\text { Diskhaler", } \\
\text { "placebo } \\
\text { Diskhaler" }\end{array}$ & $\begin{array}{l}\text { Double blind, } \\
\text { "placebo or liquid } \\
\text { oseltamivir" }\end{array}$ & $\begin{array}{l}\text { Double blinded, } \\
\text { "oseltamivir or placebo" }\end{array}$ & $\begin{array}{l}\text { Double blind, } \\
\text { placebo inhaler }\end{array}$ & $\begin{array}{l}\text { Double blind, } \\
\text { placebo inhaler }\end{array}$ & Open label \\
\hline $\begin{array}{l}\text { Incomplete } \\
\text { outcome data }\end{array}$ & $\begin{array}{l}\text { Intention to treat analysis } \\
\text { "primary analysis included } \\
\text { participants with } \\
\text { incomplete or missing } \\
\text { data" }\end{array}$ & $\begin{array}{l}\text { Intention to treat } \\
\text { analysis, } \\
\text { insufficient details }\end{array}$ & $\begin{array}{l}\text { Appropriate } \\
\text { censoring and } \\
\text { statistical tests }\end{array}$ & $\begin{array}{l}\text { Appropriate censoring } \\
\text { and statistical tests }\end{array}$ & $\begin{array}{l}\text { Intention to treat } \\
\text { analysis, low } \\
\text { discontinuation }\end{array}$ & $\begin{array}{l}\text { Intention to treat } \\
\text { analysis, low } \\
\text { discontinuation }\end{array}$ & $\begin{array}{l}\text { Intention to treat } \\
\text { analysis, low } \\
\text { discontinuation }\end{array}$ \\
\hline $\begin{array}{l}\text { Free of selective } \\
\text { reporting }\end{array}$ & Yes & $\begin{array}{l}\text { Missing } 95 \% \mathrm{Cl} \text { for } \\
\text { medians }\end{array}$ & Yes & $\begin{array}{l}\text { Only reported confirmed } \\
\text { influenza and per } \\
\text { protocol populations }\end{array}$ & Yes & Yes & Yes \\
\hline
\end{tabular}

${ }^{\star}$ Not published in peer reviewed journal. 
Table 4 |Effects of treatment on resolution of influenza symptoms, resolution of illness, and return to school or normal activities

\begin{tabular}{|c|c|c|c|c|c|c|c|c|c|}
\hline \multirow[b]{2}{*}{ Study } & \multicolumn{3}{|c|}{$\begin{array}{c}\text { Median days to resolution or alleviation of } \\
\text { symptoms }\end{array}$} & \multicolumn{3}{|c|}{ Median days to resolution of illness* } & \multicolumn{3}{|c|}{ Days to return to school/normal activities } \\
\hline & Antiviral & Control & Difference $(95 \% \mathrm{Cl})$ & Antiviral & Control & Difference $(95 \% \mathrm{Cl})$ & Antiviral & Control & Difference $(95 \% \mathrm{Cl})$ \\
\hline \multicolumn{10}{|c|}{ Confirmed influenza } \\
\hline \multicolumn{10}{|l|}{ Zanamivir: } \\
\hline NAl30009w2 & 4.0 & 5.25 & $\begin{array}{c}1.25(0.5 \text { to } 2.0) \\
\quad P<0.001\end{array}$ & - & - & - & NR & NR & 1 day $(\mathrm{NA}), \mathrm{P}=0.022$ \\
\hline NAl30028 ${ }^{\mathrm{w} 1}$ & 5.0 & 5.5 & 0.5 (NA), $P=N A$ & - & - & - & $\begin{array}{c}36 \%(62 / \\
172) \text { at day } 5\end{array}$ & $\begin{array}{c}28 \%(25 / 89) \\
\text { at day } 5\end{array}$ & $\begin{array}{c}\mathrm{RD}=0.08(0.04 \text { to } 0.20), \\
P=0.19\end{array}$ \\
\hline \multicolumn{10}{|l|}{ Oseltamivir: } \\
\hline WV15758 W3 & 2.6 & 4.2 & 1.5 (NA) P<0.001 & 4.2 & 5.7 & $\begin{array}{c}1.5 \text { (0.3 to } 2.5) \\
\quad P<0.001\end{array}$ & NR & NR & NR \\
\hline $\begin{array}{l}\text { WV15759/ } \\
\text { WV15871 }\end{array}$ & 3.8 & 4.8 & $1.1(\mathrm{NA}), \mathrm{P}=0.12$ & 5.2 & 5.6 & 0.4 (NA), $P=0.54$ & $4.2 \dagger$ & $4.8 \dagger$ & $0.5(\mathrm{NA}), \mathrm{P}=0.46$ \\
\hline \multicolumn{10}{|c|}{ Clinical influenza } \\
\hline \multicolumn{10}{|l|}{ Zanamivir: } \\
\hline NAl30009 $9^{\mathrm{w} 2}$ & 4.5 & 5.0 & $\begin{array}{l}0.5 \text { (0.0 to } 1.5) \\
P=0.011\end{array}$ & - & - & - & NR & NR & 1 day $(N A), P=0.019$ \\
\hline NAl30028 $8^{\mathrm{w} 1}$ & - & - & - & - & - & - & - & - & - \\
\hline \multicolumn{10}{|l|}{ Oseltamivir: } \\
\hline WV15758 w3 & NR & NR & $N R$ & 4.4 & 5.3 & $\begin{array}{l}0.9 \text { (0.2 to } 1.9) \\
P<0.001\end{array}$ & NR & NR & NR \\
\hline $\begin{array}{l}\text { WV15759/ } \\
\text { WV15871 }^{\text {w4 }}\end{array}$ & NR & NR & NR & NR & NR & NR & NR & NR & NR \\
\hline
\end{tabular}

$\mathrm{RD}=$ risk difference; $\mathrm{NR}=$ outcome assessed in study but not results not reported; $\mathrm{NA}=$ not available.

*Defined as alleviation of symptoms + return to normal activities + afebrile.

†Median.

All four treatment studies reported on the incidence of nausea, vomiting, and diarrhoea. Combination of data from all four trials that reported vomiting showed significant heterogeneity $\left(\mathrm{I}^{2}=75 \%\right)$. Subgroup analysis of the two trials of zanamivir showed no significant increase in vomiting (risk difference $0.00,-0.02$ to $\left.0.02, \mathrm{P}=0.82, \mathrm{I}^{2}=0 \%\right)$, ${ }^{\mathrm{w} 1}$ w2 whereas the two trials of oseltamivir showed an additional one in 20 children treated would have vomiting $(0.05,0.02$ to $0.09, \mathrm{P}=0.007$, $\left.\mathrm{I}^{2}=0 \%\right) .{ }^{\mathrm{w} 3} \mathrm{w} 4$ Overall, vomiting occurred in $6.7 \%$ (57/ 852) of untreated children with clinical influenza. ${ }^{\text {wl-w4 }}$ In addition, there was a low incidence of nausea $(3.4 \%$, $29 / 852)$ and diarrhoea $(6.6 \%, 56 / 852)$. Neither was affected by treatment with neuraminidase inhibitors $\left(-0.01,-0.03\right.$ to $0.00, \mathrm{P}=0.06, \mathrm{I}^{2}=0 \%$, and -0.01 , -0.03 to $0.00, \mathrm{P}=0.16, \mathrm{I}^{2}=0 \%$, respectively).

The two trials of zanamivir for prophylaxis stated that the incidence of adverse events was similar between treatment and control groups but did not provide quantitative data on the paediatric subgroups. ${ }^{\mathrm{w} 5 \mathrm{w} 6}$ No deaths were reported.

\section{DISCUSSION}

Treatment of influenza in children with zanamivir and oseltamivir provided a more rapid resolution of symptoms and resolution of illness generally (resolution of symptoms and fever and return to school or normal activity) by between 0.5 to 1.5 days. These reductions, however, were not all significant, leaving uncertainty in both the size and confidence in these effects. Because of inadequate reporting of trial data and heterogeneity of the studies we were unable to pool results. Effects on individual symptoms were also not consistent. Cough was significantly reduced by treatment in two trials and fever in one of two trials; for both symptoms the magnitude of effect, when reported, was about one day. Children given oseltamivir or zanamivir returned to school or normal activity between 0.5 and 1 day more rapidly than those in control groups. By day five of the illness, however, only a third of children in either group had returned to school or normal activity. Furthermore, clinicians should be aware that for one in 10 children symptoms of influenza might persist for more than two weeks.

The effects on complications showed inconsistent results. Oseltamivir and zanamivir showed little or no effect on the number of asthma exacerbations, with oseltamivir providing a small improvement in $\mathrm{FEV}_{1}$ in the first six days of illness in only one trial. Moreover, effects on rates of otitis media were no different in children aged 5-6 and 12 but were significantly lower in children younger than 5 . With a household prophylaxis strategy, 13 children would need to be treated with a 10 day course of zanamivir or oseltamivir to prevent one additional child developing influenza. Finally, zanamivir seemed to cause no more side effects than placebo, whereas oseltamivir was associated with an additional one in 20 children treated developing vomiting.

\section{Comparison with existing literature}

This review adds to our Cochrane review updated in 2005, which included only three trials of treatment and one on postexposure prophylaxis. ${ }^{9}$ It concluded that neuraminidase inhibitors were effective in shortening the duration of illness and showed no significant effect 
Table 5| Ongoing trials of neuraminidase inhibitors for influenza in children

\begin{tabular}{|c|c|c|c|c|c|}
\hline Identifier & Methods & Participants & Interventions & Outcomes & Details \\
\hline NCT00412737 & $\begin{array}{l}\text { Seasonal prophylaxis for } \\
12 \text { weeks }\end{array}$ & $\begin{array}{l}\text { Transplant recipients. Age >1. } \\
\text { Negative for influenza. } \\
\text { Confirmed influenza }\end{array}$ & Oseltamivir v placebo & $\begin{array}{l}\text { Primary: percentage of patients } \\
\text { with laboratory confirmed } \\
\text { clinical influenza }\end{array}$ & $\begin{array}{l}\text { CD: Nov 2008. Hoffmann-La } \\
\text { Roche }\end{array}$ \\
\hline NCT00593502 & $\begin{array}{l}\text { Prevention of otitis media in } \\
\text { young otherwise healthy } \\
\text { children with symptomatic } \\
\text { influenza }\end{array}$ & $\begin{array}{l}\text { Age } 1 . \text { Healthy children. } \\
\text { Confirmed influenza. Within } 24 \\
\text { hours of symptoms }\end{array}$ & Oseltamivir $v$ placebo & $\begin{array}{l}\text { Primary: incidence of otitis } \\
\text { media. Secondary: time to } \\
\text { resolution of fever and other } \\
\text { symptoms }\end{array}$ & $\begin{array}{l}\text { CD: June 2009. Hospital District } \\
\text { of Southwestern Finland. } \\
\text { Hoffmann-La Roche }\end{array}$ \\
\hline NCT00555893 & $\begin{array}{l}\text { Treatment }\langle 48 \mathrm{~h} v>48 \mathrm{~h} \text { after } \\
\text { symptoms }\end{array}$ & Age $>1$. Clinical influenza & Oseltamivir $v$ placebo & $\begin{array}{l}\text { Primary: duration of influenza } \\
\text { illness. Secondary: secondary } \\
\text { attack rate, secondary } \\
\text { complications }\end{array}$ & $\begin{array}{l}\text { ECD: Feb 2011. Marshfield Clinic } \\
\text { Research Foundation }\end{array}$ \\
\hline NCT00707941 & $\begin{array}{l}\text { Treatment }\langle 48 \mathrm{~h} v>48 \mathrm{~h} \text { after } \\
\text { symptoms, and placebo }\end{array}$ & $\begin{array}{l}\text { Age >1. Population: Bangladesh, } \\
\text { urban slum. Confirmed } \\
\text { influenza }\end{array}$ & Oseltamivir $v$ placebo & $\begin{array}{l}\text { Primary: duration of clinical } \\
\text { illness, clinical complications }\end{array}$ & $\begin{array}{l}\text { ECD: Dec 2009. International } \\
\text { Centre for Diarrhoeal Disease } \\
\text { Research, Bangladesh }\end{array}$ \\
\hline NCT00545532 & $\begin{array}{l}\text { Standard } v \text { high dose } \\
\text { oseltamivir in transplant } \\
\text { recipients }\end{array}$ & $\begin{array}{l}\text { Age }>1 \text {. Transplant recipients on } \\
\text { immunosuppression. } \\
\text { Confirmed influenza. Treatment } \\
<48 \mathrm{~h}\end{array}$ & $\begin{array}{l}\text { Oseltamivir standard } v \text { high } \\
\text { dose. }\end{array}$ & $\begin{array}{l}\text { Primary: time to alleviation of all } \\
\text { clinical symptoms. Secondary: } \\
\text { secondary illness/ } \\
\text { complications }\end{array}$ & $\begin{array}{l}\text { ECD: Oct 2010. Hoffmann-La } \\
\text { Roche }\end{array}$ \\
\hline NCT00867139 & $\begin{array}{l}\text { Triple combined antivirals } v \\
\text { monotherapy for influenza } A \text { in } \\
\text { immunocompromised } \\
\text { participants }\end{array}$ & $\begin{array}{l}\text { Age } \geq 7 \text {. Immunocompromised. } \\
\text { Confirmed influenza }\end{array}$ & $\begin{array}{l}\text { Amantadine + ribavirin + } \\
\text { oseltamivir } v \text { zanamivir or } \\
\text { oseltamivir }\end{array}$ & $\begin{array}{l}\text { Primary: safety. Secondary: } \\
\text { duration of symptoms }\end{array}$ & $\begin{array}{l}\text { ECD: Dec 2010. Fred Hutchinson } \\
\text { Cancer Research Center }\end{array}$ \\
\hline NCT00298233 & $\begin{array}{l}\text { Standard } v \text { high dose } \\
\text { oseltamivir in severe or avian } \\
\text { influenza }\end{array}$ & $\begin{array}{l}\text { Age }>1 \text { (some centres). Severe } \\
\text { symptoms or avian influenza. } \\
\text { Confirmed influenza }\end{array}$ & $\begin{array}{l}\text { Oseltamivir; standard } v \text { high } \\
\text { dose }\end{array}$ & $\begin{array}{l}\text { Primary: negative RT-PCR from } \\
\text { nasal swabs. Secondary: } \\
\text { includes frequency of clinical } \\
\text { failure }\end{array}$ & $\begin{array}{l}\text { CD: Feb 2009. National Institute } \\
\text { of Allergy and Infectious } \\
\text { Diseases }\end{array}$ \\
\hline
\end{tabular}

$C D=$ completion date; $E C D=$ estimated completion date.

on prophylaxis. This review, which included an additional treatment trial, found insufficient data to allow pooling, but the effects reported are consistent enough to conclude that treatment results in 0.5 to 1.5 day reduction in influenza symptoms or illness, or both. In the present review, we also obtained data of postexposure prophylaxis from two additional trials, which allows us to be more certain about the effect on contact cases $(\mathrm{P}<0.001)$. A systematic review of neuraminidase inhibitors for treatment and prevention of influenza in adults concluded that both zanamivir and oseltamivir provided small beneficial effects for alleviating symptoms; the ratio of the median times to resolution between the treatment and placebo groups were 1.33 and 1.30 , respectively. ${ }^{15}$ In adults, both drugs were effective at postexposure prophylaxis in people with confirmed influenza but not those with influenza-like illness. ${ }^{15}$

Our findings also suggest that any effects present were less in children with clinically defined influenza than in those with microbiologically confirmed influenza. This might present a problem in seasonal influenza in primary care, where the accuracy of clinical diagnosis (without near patient testing) might be limited. ${ }^{16}$ For example, influenza was detected in only $30-39 \%$ of nasopharyngeal swabs submitted for virological surveillance in children attending UK general practices with influenza-like illness during three successive winter seasons. ${ }^{17}$ In pandemic influenza, however, a greater proportion of children presenting with influenza-like symptoms are likely to have influenza, which would tend to increase the apparent efficacy of neuraminidase inhibitors in clinical cases. The difference in the effect of oseltamivir and zanamivir on secondary complications of influenza such as otitis media and the subsequent use of antibiotics might be due to the low systemic absorption of inhaled zanamivir compared with oral oseltamivir, which has $80 \%$ bioavailability and good penetration to middle ear and sinuses, or due to the age groups selected for the zanamivir trials. ${ }^{18}$ Reductions of secondary complications could be an important factor in the decision to treat and should be balanced with the higher rates of adverse effects, particularly vomiting, with oseltamivir.

\section{Strengths and weaknesses of review}

Our review has some limitations. Firstly, our search strategy, while comprehensive, might have missed published and unpublished trials. Although our search was comprehensive and builds on previous Cochrane search strategies, important negative findings might not have been published beyond the conference abstract stage. We have addressed this issue to some extent by obtaining unpublished data from one manufacturer. We are also aware of seven ongoing randomised controlled trials of neuraminidase inhibitors in children, as well as several studies involving the current pandemic strain, which might affect the findings of this review (table 5). Secondly, study quality was generally moderate, with only one of seven included studies rated free from bias, and the quality of the others was limited by poor reporting. Thirdly, studies varied both in the outcomes measured and the consistency of reporting of results, which severely hampered our ability to aggregate results. Fourthly, there were few data on children with comorbidities, with only a single trial of children with asthma: trials excluded "high risk" children such as those who are 


\section{WHAT IS ALREADY KNOWN ON THIS TOPIC}

Children are particularly vulnerable to seasonal epidemics of influenza, and some will go on to develop secondary complications

The neuraminidase inhibitors oseltamivir and zanamivir are used for treating children with symptomatic influenza and preventing infection in contacts

In the current A/H1N1 pandemic, neuraminidase inhibitors have been used for prophylaxis and are currently recommended for the empirical treatment of children with influenza-like illness

\section{WHAT THIS STUDY ADDS}

Antivirals (oseltamivir and zanamivir) shorten the median duration of influenza by 0.5 to 1.5 days and reduce transmission of influenza by $8 \%$

Antiviral treatment does not have a clinically significant effect on reducing asthma exacerbations or on overall use of antibiotics, but oseltamivir is associated with an increased risk of vomiting

The effects of antivirals on reducing the course of illness or preventing complications in children with the current influenza pandemic are not known but, based on current evidence, might be limited

immunosuppressed or with chronic cardiac or respiratory problems. Fifthly, there was significant heterogeneity in the rates of vaccination between the trials, ranging from $2 \%$ to $20 \%$, which might reduce the apparent efficacy as the severity of influenza illness is often milder in vaccinated than in unvaccinated children. ${ }^{19}$ Finally, none of the studies was sufficiently powered to determine the effects of neuraminidase inhibitors on serious complication of influenza (such as pneumonia or admission to hospital), and we found no evidence from these trials on efficacy and safety in children aged under 1 .

\section{Implications for seasonal and pandemic influenza}

For children with seasonal influenza neuraminidase inhibitors seem to have a small effect in terms of reducing duration of illness of between 0.5 and 1.5 days. There is currently no evidence to single out special treatment for children with asthma. It is difficult to know the extent to which these findings can be generalised to children in the current $\mathrm{A} / \mathrm{H} 1 \mathrm{~N} 1$ pandemic. At present, most cases in children have been mild, but recommendations in several countries encourage treatment of children with suspected or confirmed A/ H1N1 flu. While morbidity and mortality in the current pandemic remain low, a more conservative strategy might be considered prudent, given the limited data, side effects such as vomiting, and the potential for developing resistant strains of influenza.

Use of neuraminidase inhibitors to limit the spread of influenza is a key component of containment strategies. The evidence of magnitude of this effect (at least for seasonal influenza) is now clear: 13 people need to be treated to prevent one additional case. In a prolonged pandemic, however, those most likely to be treated (such as healthcare professionals) might require multiple courses as the number of contacts escalates.

\section{Further areas for research}

In the seven randomised controlled trials currently under way, six are treatment trials and one a prophylaxis trial (table 5). Three of the trials are being undertaken in immunocompromised children and one in children in a developing country. These trials might also provide some data to help guide clinicians and parents in the current influenza pandemic, as well as data on effects in children with comorbidities, who might be at higher risk of complications. Defining the role of antibiotics in reducing complications from secondary infections in seasonal and pandemic influenza must also be a priority as there are observational data to show that antibiotics provide a small benefit in children with seasonal influenza. ${ }^{20}$ In the UK and the US oseltamivir is not licensed for children aged under 1 . This limitation was supported by animal studies that found that high doses caused death in juvenile but not adult rats, with a disproportionately high concentration of the drug found in the brain. ${ }^{21}$ We did not find any randomised trial data in this age group, but we are aware of two case series in 148 children aged under 1 treated with oseltamivir, which found no mortality or encephalitis. ${ }^{2223}$ In the current pandemic, there is a pressing need to understand the benefits and potential adverse effects of these drugs as the current evidence base supporting this age boundary is limited.

The Department of Primary Health Care is a member of the NIHR funded School of Primary Care Research. Richard Mayon-White provided valuable advice on drafts of the manuscript. Nia Roberts provided assistance with literature searching and organisation. We also thank Nic Matheson, Mkael Symmonds-Abrahams, Sasha Shepherd, and Aziz Sheikh, who were involved in the previous Cochrane systematic review, and GlaxoSmithKline (Alison Webster) and Roche (James Smith) for providing data.

Contributors: MS-S and MT conducted the searches, collated and reviewed the studies, extracted the data, performed the initial analysis, and wrote the initial draft. $\mathrm{CH}$ and RP contributed to the analysis, revised and commented on various drafts, and provided methodological support. $\mathrm{AH}$ conceived the idea for and the design of the study and wrote the initial protocol. DM revised and commented on various drafts. All authors contributed to the final report. MT is guarantor.

Funding: This research received no specific grant from any funding agency in the public, commercial, or not-for-profit sectors. The Department of Primary Health care is part of the NIHR School of Primary Care Research. Competing interests: None declared.

Ethical approval: Not required.

1 Glezen WP, Couch RB. Interpandemic influenza in the Houston area, 1974-76. N Engld J Med 1978;298: 587-92.

2 Poehling KA, Edwards KM, Weinberg GA, Szilagyi P, Staat MA, Iwanr MK, et al. New Vaccine Surveillance Network. The under recognized burden of influenza in young children. $N$ Engl J Med 2006;355:31-40.

3 Neuzil KM, Zhu Y, Griffin MR, Edwards KM, Thompson JM, Tollefson SJ, et al. Burden of interpandemic influenza in children younger than 5 years: a 25 -year prospective study. J Infect Dis 2002;185:147-52.

4 Bhat N, Wright JG, Broder KR, Murray AL, Greenberg ME, Glover MJ, et al. Influenza-associated deaths among children in the United States, 2003-2004. N Engl J Med 2005;353:2559-67. 
5 Health Protection Agency. HPA weekly national influenza report: week 27. 2009 July 1. www.hpa.org.uk/web/

HPAweb\&HPAwebStandard/HPAweb_C/1243928258754.

6 Jefferson T, Rivetti A, Harnden A, Di Pietrantonj C, Demicheli V. Vaccines for preventing influenza in healthy children. Cochrane Database Syst Rev 2008;(2):CD004879.

7 Jefferson T, Demicheli V, Di Pietrantonj C, Rivetti D. Amantadine and rimantadine for influenza A in adults. Cochrane Database Syst Rev 2008;(2):CD001169.

8 National Institute for Health and Clinical Excellence. Amantadine, oseltamivir, and zanamivir for the treatment of influenza. London: NICE, 2009.

9 Matheson NJ, Harnden AR, Perera R, Sheikh A, Symmonds-Abrahams M. Neuraminidase inhibitors for preventing and treating influenza in children. Cochrane Database Syst Rev 2007;(1):CD002744.

10 National Institute for Health and Clinical Excellence. Oseltamivir, amantadine and zanamivir for the prophylaxis of influenza. London: NICE, 2009.

11 Tappenden P, Jackson R, Cooper K, Rees A, Simpson E, Read R, et al. Amantadine, oseltamivir and zanamivir for the prophylaxis of influenza (including a review of existing guidance no. 67): a systematic review and economic evaluation. Health Technol Assess 2009;13:1-246.

12 Higgins JPT, Altman DG (eds). Assessing risk of bias in included studies. In: Higgins JPT, Green S, eds. Cochrane handbook for systematic reviews of interventions.Version 5.0.1 (updated September 2008). Cochrane Collaboration, 2008. www.cochrane-handbook.org

13 Higgins JP, Thompson SG, Deeks JJ, Altman DG. Measuring inconsistency in meta-analyses. BMJ 2003;327:557-60.

14 Jacobs B, Young NL, Dick PT, Ipp MM, Dutkowski R, Davies HD, et al. Canadian acute respiratory illness and flu scale (CARIFS): development of a valid measure for childhood respiratory infections. J Clin Epidemiol 2000;53:793-9.

15 Jefferson T, Demicheli V, Rivetti D, Jones M, Di Pietrantonj C, Rivetti A. Antivirals for influenza in healthy adults: systematic review. Lancet 2006;367:303-13.

16 Rodriguez WJ, Schwartz RH, Thorne MM. Evaluation of diagnostic tests for influenza in a pediatric practice. Pediatr Infect Dis J 2002;21:193-6.

17 Zambon M, Hays J, Webster A, Newman R, Keene O. Diagnosis of influenza in the community: relationship of clinical diagnosis to confirmed virological, serologic, or molecular detection of influenza. Arch Intern Med 2001;161:2116-22.

18 Hayden FG. Influenza virus neuraminidase inhibitors: clinical aspects. Int Congr Ser 2001;1219:797-806.

19 Belshe RB, Mendelman PM, Treanor J, King J, Gruber WC, Piedra P, et al. The efficacy of live attenuated, cold-adapted, trivalent, intranasal influenza virus vaccine in children. $N$ Engl J Med 1998;338:1405-12.

20 Harnden A, Perera R, Brueggemann AB, Mayon-White R, Crook DW, Thomson A, et al. Respiratory infections for which general practitioners consider prescribing an antibiotic: a prospective study. Arch Dis Child 2007;92:594-7.

21 FDA. Dear Doctor. 2003 December. www.fda.gov/downloads/ Safety/MedWatch/Safetylnformation/ SafetyAlertsforHumanMedicalProducts/UCM169493.pdf.

22 Okamoto S, Kamiya I, Kishida K, Shimakawa T, Fukui T, Morimoto T. Experience with oseltamivir for infants younger than 1 year old in Japan. Pediatr Infect Dis / 2005;24:575-6.

23 Tamura D, Miura T, Kikuchi Y. Oseltamivir phosphate in infants under 1 year of age with influenza infection. Pediatr Int 2005;47:484.

Accepted: 3 August 2009 